\title{
Giant Bladder Stone in a Young Woman
}

\author{
Genç Kadında Dev Mesane Taşı \\ Özkan Onuk, Mustafa Bahadır Can Balcı, Aydın İsmet Hazar, Tuncay Taş, Arif Özkan, Barış Nuhoğlu \\ Gaziosmanpaşa Taksim Emergency Training and Research Hospital, Urology, İstanbul, Turkey
}

\section{ABSTRACT}

Bladder stones heavier than $100 \mathrm{~g}$ are defined as giant bladder stones. Bladder stones occur rarely in women compared to men. Bladder stones in women generally occur secondary to passage of suture material through the bladder following pelvic or gynecologic surgery. The disease is frequently manifested clinically with hematuria, recurrent urinary tract infection or urine retention. In this article, a 31-year-old woman who presented with nonspecific urinary tract symptoms and was found to have a giant bladder stone with a weight of $280 \mathrm{~g}$ as a result of the studies performed is presented. (JAREM 2014; 4: 132-4)

Key Words: Young woman, giant bladder stone, sistolithotomy

\section{ÖZET}

Ağırlığı 100 gr.`ı üzerindeki mesane taşları dev mesane taşı olarak tanımlanır. Erkeklere nazaran kadınlarda mesane taşları nadir olarak görülmektedir. Genellikle kadınlarda mesane taşları pelvik ya da jinekolojik cerrahi sonrası sütür materyalinin mesaneden geçmesine ikincil oluşmaktadır. Hastalar sıklıkla hematüri, tekrarlayan idrar yolu enfeksiyonu veya idrar retansiyonu seklinde klinik bulgu verir. Bu yazıda, özgün olmayan üriner sistem belirtileri ile başvuran ve yapılan tetkikleri sonucu 280 gr ağırlığındaki dev mesane taşı tespit edilen 31 yaşındaki bir kadın hasta sunulmuştur. (JAREM 2014; 4: 132-4)

Anahtar Sözcükler: Genç kadın, dev mesane taşı, sistolitotomi

\section{INTRODUCTION}

In current urology practice, bladder stones heavier than $100 \mathrm{~g}$ are encountered uncommonly (1). Bladder stones occur very rarely in women. The fact that the urethra is shorter in women compared to men is a factor which facilitates elimination of bladder stones. Bladder stones in women generally occur secondary to passage of suture material through the bladder following pelvic or gynecologic surgery. In addition, neurogenic bladder, chronic bacteriuria due to urease producing bacteria, diverticulis and inadequeate nutrition have been reported as factors leading to bladder stone. Bladder stones may lead to adverse effects including acute urinary retention, bladder tumor due to chronic irritation, bilateral hydronephrosis and related renal failure (2).

\section{CASE PRESENTATION}

A 31-year-old female patient presented to our clinic with complaints of dysuria, pollacuria, urinary incontinence and blood in urine. It was learned that the patient had a history of passing stone at the age of 20 and was treated for the last 3 years because of recurrent urinary tract infection. On physical examination, a solid mass was found in the suprapubic region. Urinalysis revealed hematuria and pyuria. On ultrasonography and computed tomography, an appearance compatible with bladder stone with a size of $8 \mathrm{~cm}$ in the long axis which did not caused hydronephrosis was observed (Figure 1).

Ceftriaxon treatment was started and E.coli was isolated in the urinary culture. No growth was found in the urinary culture obtained on the $10^{\text {th }}$ day of antibiotic treatment. Urethrocystoscopy was performed to exclude urthral pathologies. The urethra was observed to be normal and a giant urinary tract stone was observed in the bladder (Figure 2)

On the same session the bladder was removed by cystolithotomy (Figure 3).

The drain was removed on the first day and the patient was discharged on the $2^{\text {nd }}$ day after surgery. The stone was found to have a size of $8.3 \times 5.0 \times 7.5 \mathrm{~cm}$ and a weight of $280 \mathrm{~g}$ (Figure 4).

Analysis of the stone revealed that it contained calcium phosphate and magnesium phosphate. On the follow-up visits at the $1,2,3$ and $6^{\text {th }}$ months, clinical and biochemical tests were found to be normal.

\section{DISCUSSION}

Bladder stones heavier than $100 \mathrm{~g}$ are defined as giant bladder stones (1). Bladder stones constitute only $5 \%$ of the stones observed in the whole urinary tract (3). The frequency of stones in the urinary tract in women is very low. $95 \%$ of all bladder stones are observed in men (4). Suspicion is an important requisite in the diagnosis of bladder stones in women. Symptoms caused by bladder stones are nonspecific. History of pollacuria, dysuria, obstruction in the urinary flow, microscopic hematuria and suprapubic pain is helpful but not pathognomonic for the disease. A giant bladder stone can be palpated on rectal, vaginal or abdominal examination, but physical examination alone is not enough for the diagnosis of bladder stone $(1,5)$. Abdominal $x$ ray and ultrasonography may be helpful in the diagnosis, but the definite diagnosis is made by cystoscopy (5). Although bladder 


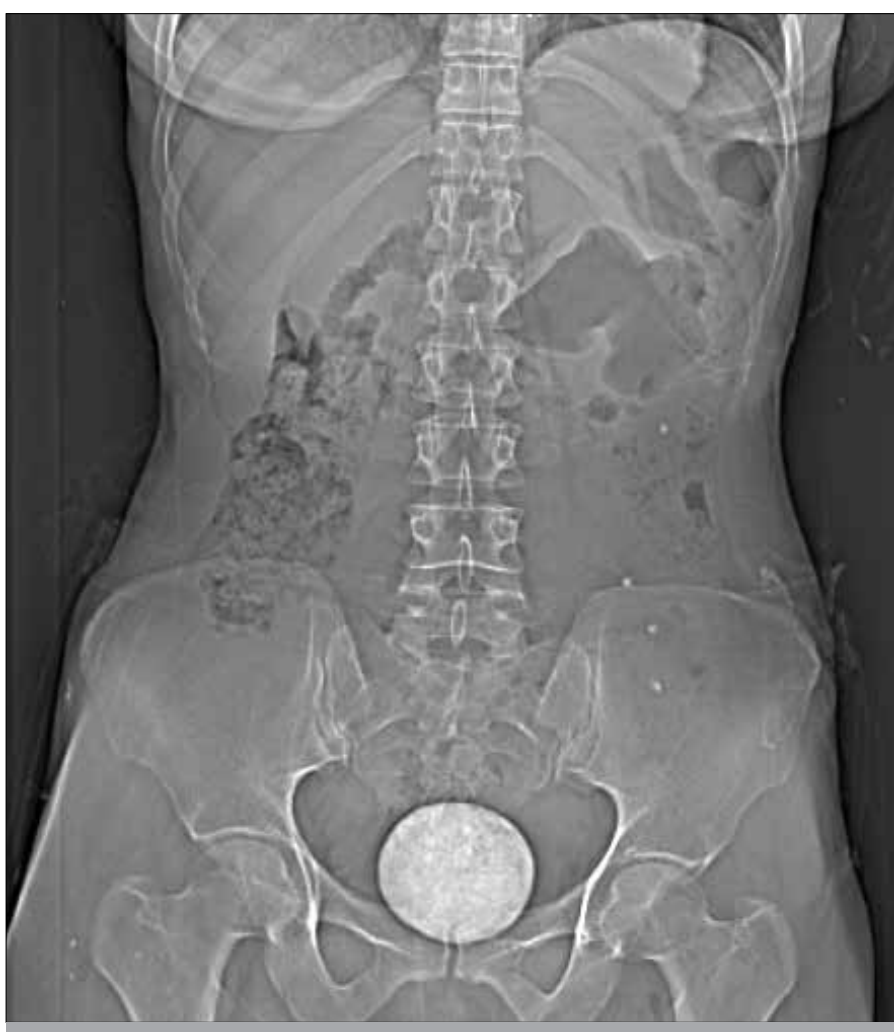

Figure 1. Computed Tomography

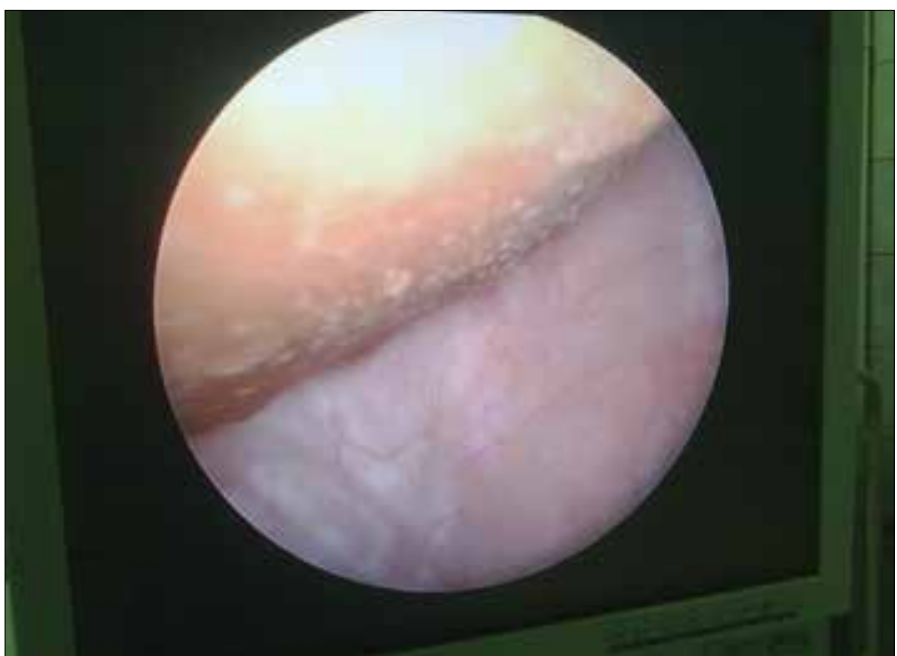

Figure 2. Appearance of cystoscopy

stones generally suggest urinary tract obstruction, they may occur secondary to stones in the kidney or urether (6). Infravesical obstruction in women is an uncommon condition. It has rarely been reported to have occured secondary to trauma, catheterization, neurogenic bladder and foreign body. Bladder stones have been reported to occur around sutures, catheters or other objects found in the bladder (4). Most bladder stones contain triphosphate, calcium carbonate and calcium oxalate in their composition (7). The most common surgical procedure for treatment of giant stones is open surgery (8). In patients with small bladder stones and urethral pathologies, both the urethral pathology and the bladder stone are treated endoscopically.

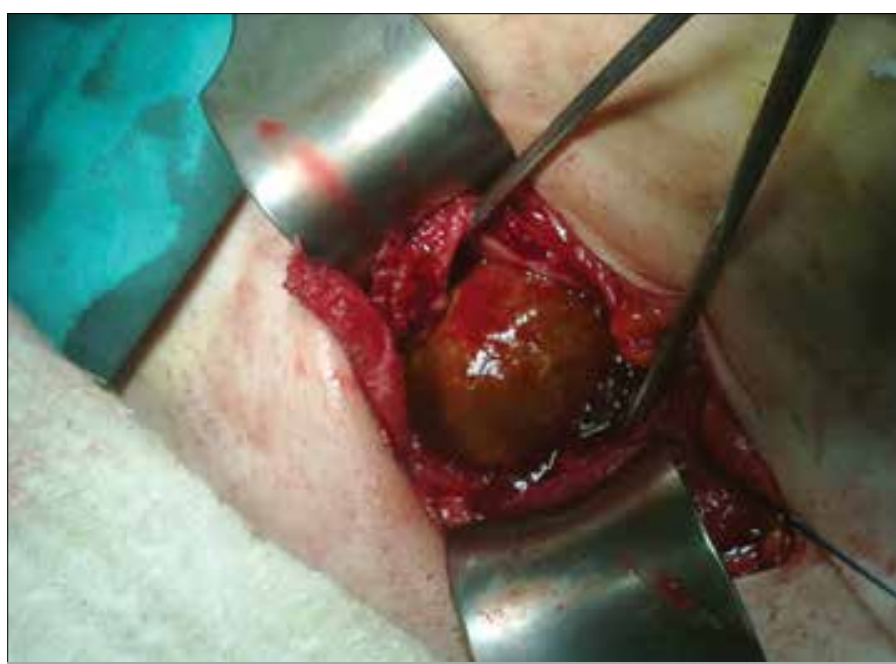

Figure 3. Appearance of cystolithotomy

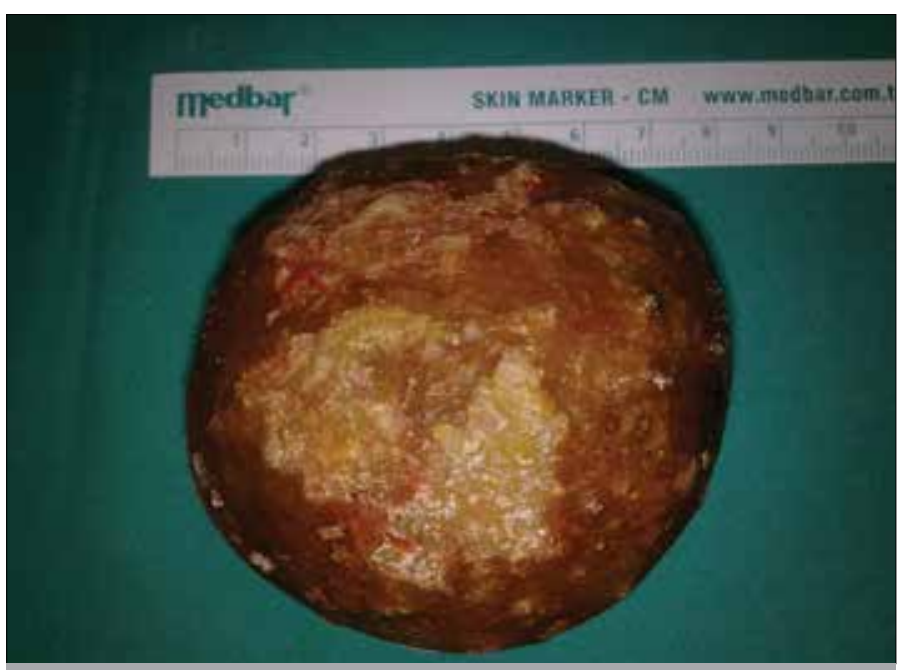

Figure 4. Bladder stone

\section{CONCLUSION}

Bladder stone is a rare condition in our urology practice. Physicians should keep in mind the possibility of bladder stone in patients with recurrent urinary tract infection though is occurs rarely and refer to imaging studies. Patients with a previous diagnosis of upper urinary tract stone and a history of stone should be followed up regularly.

Informed Consent: Written informed consent was obtained from the patient who participated in this study.

Peer-review: Externally peer-reviewed.

Author Contributions: Concept - Ö.O., A.Ö., C.B.; Design - T.T., Ö.O.; Supervision - B.N., I.H., C.B.; Funding - Ö.O., A.Ö.; Materials - T.T., C.B.; Data Collection and/or Processing - A.Ö., Ö.O.; Analysis and/or Interpretation - I.H., B.N.; Literature Review - Ö.O., T.T.; Writing - Ö.O., T.T.; Critical Review - B.N., i.H., C.B.

Conflict of Interest: No conflict of interest was declared by the authors.

Financial Disclosure: The authors declared that this study has received no financial support. 
Hasta Onamı: Yazıı hasta onamı bu olguya katılan hastadan alınmıştır.

Hakem değerlendirmesi: Dış bağımsız.

Yazar Katkıları: Fikir - Ö.O., A.Ö., C.B.; Tasarım - T.T., Ö.O.; Denetleme - B.N., I.H., C.B.; Kaynaklar - Ö.O., A.Ö.; Malzemeler - T.T., C.B.; Veri Toplanması ve/veya İşlemesi - A.Ö., Ö.O.; Analiz ve/veya Yorum - I.H., B.N.; Literatür Taraması - Ö.O., T.T.; Yazıyı Yazan - Ö.O., T.T.; Eleştirel Inceleme - B.N., I.H., C.B.

Çıkar Çatışması: Yazarlar çıkar çatışması bildirmemişlerdir.

Finansal Destek: Yazarlar bu çalışma için finansal destek almadıklarını beyan etmişlerdir.

\section{REFERENCES}

1. Becher RM, Tolia BM, Newman HR. Giant vesical calculus. JAMA 1978; 239: 2272-3. [CrossRef]
2. Çiftçi $H$, Savaş M: Dev mesane taşına bağlı tek taraflı hidronefroz. Türk Üroloji Dergisi 2008, 34: 261-3.

3. Beisland C, Andersen M. Giant urinary bladder stone [in Norwegian]. Tidsskr Nor Laegeforen 2000; 120: 573-4.

4. Pomerantz PA. Giant vesical calculus formed around arterial graft incorporated into bladder. Urology 1989; 33: 57-8. [CrossRef]

5. Schwartz BF, Stoller MZ. The vesical calculus. Urol Clin North Am 2000; 27: 333-46. [CrossRef]

6. Mckay HW, Baird HH, Lynch K. Analysis of 200 cases of urinary calculi with particular reference to methods of management of ureteral stones. Journal of the Americal Medical Association 1948; 137: 22530. [CrossRef]

7. Becher RM. Tolia BM, Newman HR. Giant vesical calculus. JAMA 1976; 239: 2272-3. [CrossRef]

8. Maneshwari PN, Oswal AT, Bansal M. Percutaneous cystolithotomy for vesical calculi : a better approach. Tech-Urol 1999; 5: 40-2. 